\title{
Novel procedures to choose the management of PPPs
}

\author{
Bruno S. Frey* \\ Permanent Visiting Professor, University of Basel and Research Director of CREMA - Center for Research in \\ Economics, Management and the Arts, Switzerland
}

\begin{abstract}
There is a large literature on public-private-partnership, covering many different areas and aspects. This article deals with a specific but important aspect: the decision-making mechanisms to choose the management of PPP enterprises. In this sector, a suitable choice of managers is of particular importance because the persons chosen must balance the public and private interests. This is often difficult to achieve. Two new procedures are discussed, "Directed Random Choice" and "Rotating CEOs". In each case, the advantages and disadvantages of the procedure of choosing the managers of PPP enterprises are discussed and evaluated. It is concluded that the two novel mechanisms should be seriously considered when choosing the managers of PPP enterprises.
\end{abstract}

Keywords: PPP enterprises; Directed Random Choice; Rotating CEOs; selection risk; diversity; burn-out; succession problem

\section{Introduction: Selecting managers of public-private enterprises}

There is an extensive literature on public-private partnerships, covering many different aspects. ${ }^{1}$ This is relevant because the combination of public and private institutions is of great and increasing importance in the modern economy. The author does not want to contribute to this literature but rather engage in an aspect less considered in academic writings: the selection of the management of public-private enterprises. To achieve efficiency with respect to the provision of infrastructure, it is essential to have suitable managers. If they are incompetent, or uninterested to perform well, this goal certainly cannot be achieved.

To identify the "best" top manager is a difficult, and sometimes nearly impossible, task in any organization. The persons involved in the selection must have a good knowledge of the education, experience and personality of the candidates. Even more difficult is to predict what the future challenges of the organization will be, and how well the various candidates are

\footnotetext{
${ }^{1}$ See e.g., Hodge and Greve (2005; 2017), Liu et al. (2014) and de Bettignies and
} Ross (2004).
ARTICLE INFO Received: Sept 23, 2019 Accepted: Nov 19, 2019 Available online: Dec 05, 2019

*CORRESPONDING AUTHOR Bruno S. Frey, CREMA - Center for Research in Economics, Management and the Arts, Suedstrasse 11, CH-8008 Zurich, Switzerland bruno.frey@bsfrey.ch

CITATION

Frey BS (2019). "Novel procedures to choose the management of PPPs". Journal of Infrastructure, Policy and Development; 3(2): 196-203. doi: $10.24294 /$ jipd.v3i2.1149 COPYRIGHT Copyright (C) 2019 by author(s) and EnPress Publisher LLC. This work is licensed under the Creative Commons Attribution-NonCommercial 4.0 International License (CC BY-NC 4.0). http://creativecommons.org/licenses/by/4.0 
likely to master them. To put much weight on past performance may be suitable if the likely problems to deal with in the future are reasonably well known. It can be expected that a manager who performed well in the past will under such condition also perform reasonably well in another organization in the future.

However, in a dynamic economy, organizations most likely will have to master tasks still unknown in the present. In a public-private enterprise, predicting what the future tasks will be is even more difficult. Relevant are not only the general economic conditions, and the particular features of the sector in which the firm is acting, but also the specific interaction between the public and private parts of the enterprise. It may be that the public influence will be reduced, in which case a person who used to act in a private firm may feel at ease and will perform well. In contrast, when political conditions develop such that the public influence in enterprises is raised, such a person may feel in the wrong place and will not be able to function in a satisfactory way. Conversely, an administrator who used to understand how public bureaucracy works might then have an advantage. The direction in which the relationship between the two spheres in a public-private firm will develop in the future is nearly impossible to predict. As a result, the choice of successful managers is particularly difficult in this realm.

The choice of managers in public-private enterprises is made by a group of persons on the basis of a set of criteria for each candidate. Specialized managing consultants may help in selecting what are considered suitable candidates. But often there are direct political influences by the government, individual politicians, as well as by highly ranked public officials. The candidate selected in that case is likely not to be the most suitable one to master future challenges. As a consequence, the selection of managers is an even greater problem in public-private enterprises than in private enterprises.

For these reasons, this paper argues that new ways should be explored to select the Chief Executive Officers ${ }^{2}$ of public-private enterprises.

This contribution discusses two novel proposals:

- The first is to establish a system of "Directed Random Selection" of Chief Executive Officers (CEOs). ${ }^{3}$ This is discussed in Section 2.

- The second novel proposal is to introduce "Rotating CEOs" (henceforward called R-CEO) for public-private organizations. ${ }^{4}$ This is discussed in Section 3.

At first glance, these two proposals are rather uncommon; they even seem to be outlandish. However, the author will try to carefully discuss the basic idea and the possible advantages as well as the disadvantages of each proposal. At the end (Section 4), the two proposals are compared and evaluated. The new light on the selection of managers of public-private enterprises should be of

\footnotetext{
${ }^{2}$ A discussion from the economic point of view is provided by Bertrand (2009).

3 See the joint work with Margit Osterloh: Osterloh and Frey (2016). Another term for randomness is sortation or selection by lot, and the application in politics is called demarchy or aleatoric democracy; see Buchstein (2010) and Frey and Osterloh (2016a; 2016b). Random choice as a general decision mechanism is discussed, e.g., in Frey (1969), Intriligator (1973), Elster (1989), Frey and Steiner (2014) and Van Reybrouck (2016).

${ }^{4}$ This section is based on joint research with Reiner Eichenberger. For a more extensive presentation, see Eichenberger and Frey (2019).
} 
interest to both academics and practitioners.

\section{Directed Random Selection of managers}

\subsection{The basic idea}

A directed random selection of managers proceeds in two steps:

- First step: A selection committee chooses candidates for the managerial positions who are considered capable of performing well. They are evaluated according to the criteria considered relevant for the position to be filled. It is important that both the desired capabilities with respect to business as well as to public administration are taken into account. This step is in line with the way CEOs of public-private enterprises are chosen today, with the substantial difference that a group of candidates considered capable is determined, instead of a single person.

- Second step: A random selection among the managers in the group is performed. The candidate determined by this aleatoric procedure is installed as CEO. ${ }^{5}$

\subsection{Advantages of Directed Random Selection}

The determination of the CEO of a public-private enterprise via a random mechanism is in various ways superior to the selection of the CEO by a committee:

- The process is efficient. It is well known that to choose the top person among a group is in most cases time-consuming and often leads to marked conflicts among the members of the selection committee. As a result, the choice procedure tends to lead to an unsatisfactory management of a firm. ${ }^{6}$ It is relatively easy to establish whether a candidate fulfills the basic requirement to lead a firm, but it is much more difficult to agree on who is best able to do that. This holds in particular because often some members of the committee introduce murky and damaging personal interests. In contrast, a random choice can be undertaken quickly and easily.

- The result is clear. When selecting by a committee, it is rarely obvious who the best candidate is because the members of the committee normally put different weights on different criteria.

- The random choice process establishes equality in the sense that every one of the contenders has the same chance of being selected. As a result, the person chosen as a CEO is less prone to be overconfident compared to the other managers. ${ }^{7}$ The danger of hubris - which tends to lead to mistaken decisions - is contained. If the contenders not chosen by lot are employed in the public-private enterprise, the winner makes an effort not to be considered pretentious or even arrogant.

5 Random selection, or aleatoric systems, have a long history starting in ancient Greece and Rome. See Sally (2002), Sintomer (2011) and Zeitoun et al. (2014).

${ }^{6}$ Bad leadership is discussed in Kellerman (2004).

7 See Hayward et al. (2004) and Malmendier and Tate (2005) 


\subsection{Disadvantages of Directed Random Selection}

Random selection has disadvantages to be taken into account:

- If a person is selected by lot out of an underlying group, possible differences in qualification are disregarded. The question is, of course, whether these differences are revealed. In principle, the criteria used by the selection committee should make clear whether a contender meets the qualifications required for the job. The problem is that these differences do not come up to the fore but remain hidden. This applies in particular to the performance of future tasks where it is not well known what the qualifications needed look like.

- Random selection will find many opponents. It is a novel idea, and such ideas are rarely accepted by a majority of the selection committee under normal circumstances. The members of such a committee tend to agree that they are well able to select the best candidate even if they disagree who he/she is. To accept a choice by lot may be interpreted by outsiders to indicate that the members of the committee are not up to their task. As a result, it is likely that random selection only has a chance to be implemented under extraordinary circumstances.

Directed random selection thus has major advantages and disadvantages, which need to be carefully compared also with other decision-making procedures.

\section{Rotating CEOs in public-private enterprises}

\subsection{The basic idea}

This selection mechanism also proceeds in two steps:

- First step: This is the same as for directed random choice. According to the criteria established, a selection committee determines the group of candidates considered capable of performing well as CEO of the public-private enterprise.

- Second step: One of the members of this team of managers is chosen as Rotating-CEO (R-CEO) for a restricted period of time. Thereafter, another member of the team becomes $\mathrm{CEO}$, and so forth.

This mechanism allows fixing several important parameters:

(a) The length over which a manager acts as R-CEO can be varied. It makes sense for the tenure not to be too short - it should probably not be less than half a year. On the other hand, no manager should be on top for a long period because he or she would accumulate too much power and may develop hubris. One year under many conditions seems to be a suitable compromise.

(b) The competences of the R-CEO can range from just being a "primus inter pares", essentially organizing the necessary meetings, to a "dictator" but with a limited period in power. The consequences for a firm are substantial, and therefore it must be carefully considered what competences are given to the R-CEO. Again, an intermediate solution may be most attractive. 
(c) The compensation of the R-CEO is different compared to that of the other members of the top management team. The difference in pay will certainly be smaller than the one typical between a sole CEO and the lower management.

\subsection{Advantages of Rotating CEOs}

Appointing R-CEOs is in various regards better than a single CEO:

- There is a smaller selection risk. If an R-CEO turns out not to be able to run the public-private enterprise successfully, his or her position ends within a foreseeable time. This contrasts to single CEOs, who sometimes cling to power though they are not performing well. ${ }^{8}$

- The overall management team is based on greater equality. Each R-CEO is well aware that he or she has to go back into the ranks of other managers. R-CEOs have an incentive to be leaders in the context of a team as their tenure will elapse. ${ }^{9}$ The tendency to dominate the rest of the team - which often occurs with a sole CEO - is avoided. Indeed, an R-CEO is interested in supporting the team spirit because he or she will benefit from it in the future when back in the ranks.

- Over time, the enterprise experiences more diversity at the top echelon. Some managers may be especially capable with respect to business issues, while others may be with respect to dealing with public sector administrators. With the system of R-CEOs, these advantages are consecutively used within the enterprise.

- As each member of the top management team is Chief only for a limited period, there is less danger of burn-out. In the system with a single CEO, it sometimes happens that the CEO loses part of his or her capacity but nevertheless stays in power.

- The leadership succession problem is strongly mitigated. This issue haunts many firms after a single CEO departs for some reason or other. ${ }^{10}$ There is regularly a period of unrest before a new CEO is appointed. This issue has become more prominent as a single CEO's period in power has on average shortened over the last decades. ${ }^{11}$

\subsection{Disadvantages of Rotating CEOs}

There are two major disadvantages of a system of R-CEOs:

- The managers acting as CEOs for a short period are not able to gain as much experience in their position as does a single CEO.

- An R-CEO has less opportunity to build up an extensive outside network within business and with the public administration and politicians. This disadvantage plays an important

\footnotetext{
8 Vancil (1987), Aasland et al. (2010), Schyns and Schilling (2013) and Sui and Humphreys (2015).

9 See also Alvarez et al. (2007), Alvarez and Svejenova (2005), Pearce (2007), Arnone and Stumpf (2010) and Arena et al. (2011). Broad reviews of distributed leaderships are provided by Bolden (2011) and Bennett et al. (2003).

${ }^{10}$ E.g., Favaro et al. (2011) and Björnberg and Feser (2015).

11 Marcec et al. (2018).
} 
role in some public-private enterprises, but not necessarily in all of them.

The system of R-CEOs has marked advantages and disadvantages over other procedures. It must be compared to other systems, taking into account different conditions.

\section{Conclusion: Comparing Directed Random Selection and Rotating CEOs for public-private enterprises}

Neither Directed Random Selection nor R-CEOs can be a system solving all major issues confronted by public-private enterprises. This holds in general but in particular also with regard to infrastructural investments. But the same is true also for the existing system of a single CEO. Which system is better depends on the specific conditions in which firms act.

This paper intends to open the discussion for two novel ways of selecting public-private top managers. An enterprise needs not depend on a single $\mathrm{CEO}^{12}$ but the two other systems proposed here allow us to choose other mechanisms to well govern a public-private enterprise.

Directed Random Selection seems a welcome procedure when it is difficult to find criteria with which to identify a sole CEO, when it is especially difficult to match job contenders to the criteria, and where it is difficult or even impossible to agree on one single person to run the public-private enterprise.

Rotating CEOs can well be applied in similar circumstances as Directed Random Selection. Indeed, the two systems can be simultaneously used: selection by lot can be used to choose an R-CEO (e.g., instead of a regular sequence between all top managers). The R-CEO system is particularly strong when a public-private enterprise has to meet the requirement of economic efficiency and political/administrative demands. In that case, persons as Chief Officers with different capabilities in the two areas may be very advantageous.

\section{References}

Aasland MS, Skogstad A, Notelaers G, MB and Einarsen S (2010). The prevalence of destructive leadership behaviour. British Journal of Management, 21(2): 438-452.

https://doi.org/10.1111/j.1467-8551.2009.00672.x.

Alvarez JL and Svejenova S (2005). Sharing Executive Power: Roles and Relationships at the Top. Cambridge, UK: Cambridge University Press. https://doi.org/10.1017/CBO9780511488504.

Alvarez JL, Svejenova S and Vives L (2007). Leading in pairs. MIT Sloan Management Review, 48(4).

Arena MP, Ferris SP and Unlu E (2011). It takes two: The incidence and effectiveness of co-CEOs. Financial Review, 46(3): 385-412. https://doi.org/10.1111/j.1540-6288.2011.00305.x.

Arnone M and Stumpf SA (2010). Shared leadership: From rivals to co - CEOs, Strategy and Leadership, 38(2): 15-21. https://doi.org/10.1108/10878571011029019.

Bennett N, Wise C, Woods PA and Harvey JA (2003). Distributed Leadership: A Review of Literature. Cambridge, UK: Open University, National College for School Leadership.

Bertrand M (2009). CEOs. Annual Review of Economics, 1: 121-150. https://doi.org/10.1146/annurev.economics.050708.143301.

Björnberg $\AA$ and Feser C (2015). CEO succession starts with developing your leaders. McKinsey Quarterly. Available from:

https://www.mckinsey.com/featured-insights/leadership/ceo-succession-starts-with-developing-your-leaders.

Bolden R (2011). Distributed leadership in organizations: A review of theory and research. International Journal of

${ }^{12}$ Henderson et al. (2006) and Quigley and Hambrick (2015) discussed to what extent CEO leadership is obsolete. 
Management Reviews, 13(3): 251-269. https://doi.org/10.1111/j.1468-2370.2011.00306.x.

Buchstein H (2010). Reviving randomness for political rationality: Elements of a theory of aleatory democracy. Constellations, 17(3): 435-454. https://doi.org/10.1111/j.1467-8675.2010.00604.x.

de Bettignies J-E and Ross TW (2004). The economics of public-private partnerships. Canadian Public Policy, 30(2): 135-154. https://doi.org/10.2307/3552389.

Eichenberger R and Frey BS (2019). Rotating CEOs. Forthcoming.

Elster J (1989). Solomonic Judgements: Studies in the Limitation of Rationality. Cambridge, UK: Cambridge University Press.

Favaro K, Karlsson P-O and Neilson GL (2011). CEO succession 2010: The four types of CEOs. Strategy + Business, Summer 2011(63).

Frey BS (1969). Wahrscheinlichkeiten als gesellschaftliche Entscheidungsregel [Probabilities as a social decision rule]. Wirtschaft und Recht, 21: 14-26.

Frey BS and Osterloh M (2016a). Aleatorische Demokratie [Aleatoric democracy]. Oekonomenstimme, December. Available from http://www.oekonomenstimme.org/artikel/2016/12/aleatorische-demokratie/.

(2016b). Aleatoric democracy. CESifo Working Paper Series No. 6229.

Frey BS and Steiner L (2014). Zufall als gesellschaftliches Entscheidungsverfahren [Random Mechanism as a social decision-making process]. In: Kaal WA, Schmidt M and Schwartze A (eds), Festschrift zu Ehren von Christian Kirchner. Recht im ökonomischen Kontext. Tübingen, Germany: Mohr Siebeck; 749-761.

Hayward MLA, Rindova VP and Pollock TG (2004). Believing one's own press: The causes and consequences of CEO celebrity. Strategic Management Journal, 25(7): 637-653. https://doi.org/10.1002/smj.405.

Henderson AD, Miller D and Hambrick DC (2006). How quickly do CEOs become obsolete? Industry dynamism, CEO tenure, and company performance. Strategic Management Journal, 27(5): 447-460. https://doi.org/10.1002/smj.524.

Hodge GA and Greve C (2005). Introduction. In: Hodge GA and Greve C (eds.), The Challenge of Public-Private Partnerships: Learning from International Experience. Cheltenham, UK: Edward Elgar; 1-21. https://doi.org/10.4337/9781845428082.

(2017). On public-private partnership performance: A contemporary review. Public Works Management \& Policy, 22(1): 55-78. https://doi.org/10.1177/1087724X16657830.

Intriligator MD (1973). A probabilistic model of social choice. Review of Economic Studies, 40(4): 553-560. https://doi.org/10.2307/2296588.

Kellerman B (2004). Bad Leadership: What It Is, How It Happens, Why It Matters. Boston, MA: Harvard Business School Press.

Liu J, Love PED, Smith J, Regan M and Sutrisna M (2014). Public-private partnerships: A review of theory and practice of performance measurement. International Journal of Productivity and Performance Management, 63(4): 499-512. https://doi.org/10.1108/IJPPM-09-2013-0154.

Malmendier U and Tate G (2005). CEO overconfidence and corporate investment. Journal of Finance, 60(6): 2661-2700. https://doi.org/10.1111/j.1540-6261.2005.00813.x.

Marcec D, Benelli K and Schulhofer A (2018). CEO tenure drops to just five years. Retrieved March 07, 2019. Available from: https://www.equilar.com/blogs/351-ceo-tenure-drops-to-five-years.html.

Osterloh M and Frey BS (2016). Chef per Zufall [Boss by lot]. WirtschaftsWoche, 47 (11 November): $111-113$.

Quigley TJ and Hambrick DC (2015). Has the "CEO Effect" increased in recent decades? A new explanation for the great rise in America's attention to corporate leaders. Strategic Management Journal, 36(6): 821-830. https://doi.org/10.1002/smj.2258.

Pearce CL (2007). The future of leadership development: The importance of identity, multi-level approaches, self-leadership, physical fitness, shared leadership, networking, creativity, emotions, spirituality and on-boarding processes. Human Resource Management Review, 17(4): 355-359. https://doi.org/10.1016/j.hrmr.2007.08.006.

Sally D (2002). Co-leadership: Lessons from republican Rome. California Management Review, 44(4): 84-99. https://doi.org/10.2307/41166144.

Schyns B and Schilling J (2013). How bad are the effects of bad leaders? A meta-analysis of destructive leadership and its outcomes. The Leadership Quarterly, 24(1): 138-158. https://doi.org/10.1016/j.leaqua.2012.09.001.

Sintomer Y (2011). Petite Histoire de l'Expérimentation Démocratique. Tirage au Sort et Politique d'Athènes à nos Jours [Between Radical and Deliberative Democracy. Random Selection in Politics from Athens to Contemporary Experiments]. Paris, France: Éditions La Découverte.

Sui J and Humphreys GW (2015). More of me! Distinguishing self and reward bias using redundancy gains. Attention, Perception, \& Psychophysics, 77(8): 2549-2561. https://doi.org/10.3758/s13414-015-0970-x. 
Vancil RF (1987). Passing the Baton: Managing the Process of CEO Succession. Cambridge, MA: Harvard Business School Press.

Van Reybrouck D (2016). Against Elections. The Case for Democracy. London, UK: Penguin Random House.

Zeitoun H, Osterloh M and Frey BS (2014). Learning from ancient Athens: Demarchy and corporate governance. Academy of Management Perspectives, 28(1): 1-14. https://doi.org/10.5465/amp.2012.0105. 